\title{
PERBEDAAN STABILITAS DIMENSI ANTARA CETAKAN ALGINAT YANG DISEMPROT DENGAN LARUTAN NATRIUM HIPOKLORIT 0,5\% DAN DETTOL 5\%
}

\author{
Wira Putri Winata ${ }^{1}$, Kuswardani Susari Putri ${ }^{2}$, Febrian ${ }^{1}$
}

\begin{abstract}
The impression materials that most commonly used in dentistry was alginate. Factors that must be considered was the controlled of infection transmission from alginate, it was important to do disinfection using a disinfectant solution. Alginate had imbibition properties, so that disinfection by spraying technique allowed the expansion of alginate affecting the dimensional stability of impressions. The purpose of this research was to determine the difference between the dimensional stability of alginate impression were sprayed with a solution of sodium hypochlorite $0,5 \%$ and Dettol ${ }^{\circledR} 5 \%$. The method used was an experimental laboratory with post test only control group design. 27 samples were divided into 3 groups: spraying with $0.5 \%$ sodium hypochlorite solution, spraying with $5 \%$ Dettol ${ }^{\circledR}$ solution, and spraying with aquades as a controlled. Alginate impressions were sprayed with $0,5 \%$ sodium hypochlorite solution, Dettol@ $5 \%$, and aquades then filled with gypsum, and then measured dimensional stability by using micrometer screw. Data were analyzed with the Kruskal-Wallis test. The results showed that differences between the dimensional stability of alginate impressions were sprayed with a solution of sodium hypochlorite $0.5 \%$ and $5 \%$ Dettol ${ }^{\circledR}$ was not significant $(p>0,05)$. The conclusion of this research was there was no significant difference between the alginate impressions were sprayed with a solution of sodium hypochlorite $0,5 \%$ and Dettol ${ }^{\circledR} 5 \%$ to dimensional stability.
\end{abstract}

Keywords : dimensional stability, alginate, sprayed, sodium hypochlorite, Dettol®

Affiliasi penulis : 1. Fakultas Kedokteran Gigi Universitas Andalas, 2. Fakultas Kedokteran Universitas Andalas

Korespondensi: Wira Putri Winata email : wiraputri.winata@gmail.com Telp: 085274652471

\section{PENDAHULUAN}

Pemakaian bahan cetak di kedokteran gigi digunakan untuk mendapatkan cetakan negatif dari rongga mulut. Hasil dari cetakan akan digunakan dalam pembuatan model studi atau model kerja yang membantu dalam rencana perawatan. ${ }^{1,2}$ Bahan cetak di kedokteran gigi dapat diklasifikasikan menjadi bahan cetak reversibel dan ireversibel. Istilah reversibel menunjukkan bahwa bahan cetak dapat melunak dengan pemanasan dan memadat dengan pendinginan karena tidak terjadi perubahan kimia. Sedangkan bahan cetak ireversibel berarti bahan tersebut tidak dapat kembali ke bentuk semula karena telah terjadi reaksi kimia.. ${ }^{3}$

Alginat (hidrokoloid irreversible) merupakan salah satu bahan cetak yang sering digunakan. ${ }^{4}$ Dokter gigi banyak menggunakan bahan cetak alginat karena memiliki banyak kelebihan, diantaranya manipulasi mudah, tidak memerlukan 
banyak peralatan, relatif tidak mahal, dan nyaman bagi pasien. ${ }^{1,5}$ Hasil survei menunjukkan penggunaan bahan cetak alginat sebagai cetakan awal yaitu sebanyak $88 \%$ di Inggris, $74 \%$ di Amerika Utara, dan $71 \%$ di India Utara. ${ }^{6}$

Faktor yang harus diperhatikan saat menggunakan bahan cetak adalah kontrol infeksi silang. Berbagai penelitian menunjukkan bahwa penggunaan bahan cetak merupakan salah satu agen penularan infeksi. ${ }^{1,7}$ Pada saat pencetakan rahang pasien, bahan cetak akan berkontak langsung dengan darah dan saliva, sehingga mikroorganisme akan menyebar melalui bahan cetak dan menjadi media penularan infeksi silang dari pasien ke dokter gigi atau petugas laboratorium., ${ }^{4,8}$ Mikroorganisme dari rongga mulut dapat bertahan pada permukaan bahan cetak dan menjadi agen penyebaran infeksi silang. ${ }^{1}$ Beberapa penelitian menunjukkan bahwa cetakan alginat dari mulut pasien mengandung mikroorganisme berbahaya seperti Staphylococcus aureus, Streptococcus sanguis, Streptococcus salivarius, Pseudomonas aeruginosa, Escherichia coli, dan Candida albicans. ${ }^{9,11,12}$ The American Dental Association (ADA) dan Centers for Disease Control and Prevention (CDC) menganjurkan bahan cetak harus dibersihkan, kemudian dilakukan tindakan desinfeksi dan dibilas dengan air mengalir. ${ }^{13,14}$ Ada dua metode desinfeksi yang disarankan oleh The American Dental Association dan Centers for Disease Control and Prevention (CDC) yaitu dengan teknik perendaman dan penyemprotan. ${ }^{15}$ Diantara kedua metode desinfeksi tersebut menunjukkan efek antibakteri yang hampir sama. ${ }^{11}$ Pertimbangan yang harus diperhatikan dalam memilih teknik desinfeksi bahan cetak yang akan dilakukan adalah pengaruh larutan desinfektan terhadap stabilitas dimensi dan detail permukaan bahan cetak, kemudian diikuti efek antibakteri. $^{16}$ Proses desinfeksi dengan cara penyemprotan lebih dianjurkan untuk mendesinfeksi bahan cetak. ${ }^{4,17}$ Teknik penyemprotan diakui sebagai metode yang efektif untuk mengurangi resiko imbibisi pada cetakan dibandingkan dengan teknik perendaman. ${ }^{16}$ Teknik penyemprotan dianggap lebih menguntungkan untuk dilakukan karena dapat mengurangi terpaparnya cetakan alginat terhadap larutan desinfektan yang bisa mengakibatkan terjadinya perubahan dimensi. $^{12}$ The American Dental Association (ADA) menyarankan penggunaan teknik penyemprotan dibanding teknik perendaman sebagai desinfeksi untuk bahan kedokteran gigi yang mengutamakan keakuratan dimensi. ${ }^{18,19}$ Bahan desinfektan yang banyak digunakan dan mempunyai 
efektivitas desinfeksi pada mikroorganisme patogen adalah natrium hipoklorit, klorheksidin, dan hidrogen peroksida. ${ }^{1}$ Untuk bahan cetak alginat, desinfektan yang direkomendasikan oleh The American Dental Association (ADA) dan Environment Protection Agency (EPA) adalah natrium hipoklorit. $^{15,20}$

Natrium hipoklorit memiliki sifat bekerja dengan cepat dan toksisitas yang rendah. ${ }^{1}$ Natrium hipoklorit banyak digunakan karena sifat toksisitas rendah, tidak terlalu mahal, dan efektif terhadap mikroorganisme spektrum luas seperti human immunodeficiency virus, virus hepatitis B, serta berbagai macam bakteri yang berhubungan dengan pekerjaan dokter gigi. ${ }^{20,21}$ Natrium hipoklorit mempunyai efek bakterisidal yang efektif terhadap bakteri gram positif dan bakteri gram negatif. ${ }^{16}$

Pemakaian natrium hipoklorit yang efektif sebagai desinfeksi yaitu pada konsentrasi 0,5\%.1,22 Penelitian yang dilakukan oleh Radcliffe dkk (2004) menunjukkan bahwa penggunaan natrium hipoklorit $0,5 \%$ efektif dalam membunuh bakteri Actinomyces naeslundii, Candida albicans, dan Enterococcus faecalis. ${ }^{23}$ Berdasarkan penelitian dari Santosh (2011) penggunaan natrium hipoklorit $0,5 \%$ menurunkan jumlah bakteri $100 \%$ pada bakteri jenis $S$. Aureus dan S.viridans yang terdapat pada cetakan. ${ }^{16}$ Penelitian yang dilakukan Bustos dkk pada tahun 2010 menunjukkan bahwa penggunaan natrium hipoklorit $0,5 \%$ selama $5-10$ menit efektif membunuh mikroorganisme. ${ }^{15}$ Penelitian yang dilakukan oleh Ghahramanloo tahun 2009 menunjukkan bahwa penyemprotan cetakan alginat dengan natrium hipoklorit $0,5 \%$ selama 10 menit efektif membunuh mikroorganisme $96,6 \%{ }^{24}$

Selain natrium hipoklorit, penggunaan cairan antiseptik dapat dijadikan sebagai bahan desinfektan. ${ }^{25}$ Dettol ${ }^{\circledR}$ dimanfaatkan secara luas penggunaannya sebagai desinfektan baik di rumah maupun dalam pelayanan kesehatan. $^{26}$ Dettol ${ }^{\circledR}$ mengandung bahan dasar utama chloroxylenol sebagai bahan aktif antibakteri. $^{27}$ Chloroxylenol dikenal sebagai antibakteri konsentrasi rendah yang memiliki spektrum luas untuk bakteri gram positif maupun gram negatif ${ }^{25}$

Berdasarkan penelitian yang dilakukan Saha dkk (2009) menunjukkan bahwa penggunaan Dettol® 5\% efektif dalam menghambat pertumbuhan bakteri Staphylococcus aureus, S.typhi, Escherricia coli, dan S.dysenteriae. ${ }^{26,28}$ Penelitian lainnya yang dilakukan oleh Mahmood dkk (2008) menunjukkan bahwa penggunaan Dettol® 5\% efektif membunuh bakteri dalam waktu 10 menit. ${ }^{27}$ Permasalahan yang dapat timbul setelah tindakan desinfeksi adalah perubahan stabilitas dimensi bahan cetak. ${ }^{1}$ 
Hal ini terjadi karena bahan cetak alginat memiliki sifat imbibisi, yaitu kemampuan alginat dalam menyerap air. Hal ini akan menyebabkan terjadinya pengembangan yang mengakibatkan perubahan stabilitas dimensi dari bahan cetak, sehingga cetakan yang dihasilkan menjadi tidak akurat. ${ }^{3}$ Penelitian Valdina dkk (2014) menunjukkan penyemprotan cetakan alginat dengan larutan natrium hipoklorit $0,5 \%$ selama 10 menit menyebabkan perubahan stabilitas dimensi alginat yang kecil. ${ }^{4}$ Berdasarkan penelitian yang dilakukan oleh Sari dkk (2013) menunjukkan bahwa cetakan alginat yang disemprot dengan natrium hipoklorit $0,5 \%$ selama 10 menit menunjukkan perubahan dimensi yang kecil. Penelitian yang dilakukan oleh Ramadhani (2016) menunjukkan bahwa cetakan alginat mengalami perubahan ukuran dimensi yang kecil setelah dilakukan perendaman dengan Dettol® 5\%.29 Oleh karena itu perlu diperhatikan bahwa tujuan desinfeksi bahan cetak secara efektif untuk membunuh mikroorganisme patogen tanpa merusak dan mengurangi keakuratan dimensinya. ${ }^{1}$ Sejauh yang penulis ketahui, belum ada penelitian yang dilakukan mengenai perbedaan stabilitas dimensi antara cetakan alginat yang disemprot dengan larutan natrium hipoklorit 0,5\% dan Dettol® 5\%. Sehingga penulis tertarik untuk melakukan penelitian mengenai perbedaan stabilitas dimensi antara cetakan alginat yang disemprot dengan larutan natrium hipoklorit $0,5 \%$ dan Dettol® $5 \%$.

\section{METODE}

Jenis penelitian yang digunakan dalam penelitian ini adalah eksperimental laboratorium dengan rancangan penelitian post test only control group design. Penelitian dilakukan pada bulan Februari 2017 di di ruang Skills Lab Fakultas Kedokteran Gigi Universitas Andalas. Sampel dalam penelitian merupakan model gipsum dari hasil cetakan alginat yang sebelumnya disemprot dengan larutan natrium hipoklorit $0,5 \%$, Dettol® 5\%, dan akuades sebagai kontrol.

\section{Pembuatan larutan desinfektan}

Jenis larutan yang digunakan adalah natrium hipoklorit $0,5 \%$ dan Dettol® 5\% yang didapatkan melalui pengenceran dengan aquades berdasarkan rumus pengenceran 30 :

$\mathrm{M} 1 . \mathrm{V} 1=\mathrm{M} 2 . \mathrm{V} 2$

\section{Pembuatan sampel cetakan alginat}

Menakar bubuk alginat dengan timbangan sebanyak 20 gram dan air sebanyak $40 \mathrm{ml}$ dengan gelas ukur. Bubuk yang telah ditakar dimasukkan ke dalam air yang juga telah ditakar pada rubber bowl. Kemudian aduk menggunakan spatula dengan menggunakan tekanan dan gerakan yang konstan yaitu gerakan angka delapan dengan putaran intermitten (1800) dalam waktu 30 detik. Hasil pengadukan 
berupa krim yang halus serta tidak menetes dari spatula ketika diangkat dari rubber bowl.Kemudian bahan cetak ditempatkan pada wadah cetak dan cetak master cast. Setelah alginat mencapai waktu pengerasan yaitu 3 menit, master cast dilepas dan hasil cetakan dibilas dibawah air mengalir selama 10 detik.

\section{Proses Desinfeksi}

Cetakan alginat disemprot dengan natrium hipoklorit 0,5\%, Dettol® 5\%, dan akuades sebanyak $\pm 8 \mathrm{ml}$ selama 30 detik. Jarak antara sprayer dengan cetakan alginat $\pm 5 \mathrm{~cm}$. Kemudian dimasukkan ke dalam kantung plastik selama 10 menit. Setelah itu dibilas lagi cetakan alginat selama 10 detik dan lakukan pengisian dengan gipsum tipe III.

\section{Pengisian hasil cetakan alginat}

Takar bubuk gipsum tipe III dengan timbangan sebanyak 50 gram dan air sebanyak $15 \mathrm{ml}$ dengan gelas ukur. Tuang bubuk gipsum yang telah ditakar ke dalam air yang telah ditakar pada rubber bowl. Kemudian aduk menggunakan spatula dengan tekanan dan gerakan yang konstan. Waktu pengadukan 1 menit. Lakukan pengisian ke dalam cetakan alginat sambil dilakukan vibrasi agar seluruh bagian cetakan alginat rata tercetak dengan gipsum. Tunggu selama 45 menit sampai gipsum mengeras. Setelah itu lepaskan model gipsum dari cetakan alginat.

\section{Pengukuran Stabilitas Dimensi}

Ukur dimensi model gipsum yaitu diameter model gipsum menggunakan mikrometer sekrup. Bandingkan ukuran dimensi antara cetakan alginat yang disemprot dengan natrium hipoklorit $0,5 \%$, Dettol® 5\%, dan akuades.

\section{HASIL}

Tabel 5.1 Rata- rata diameter model gipsum setelah penyemprotan

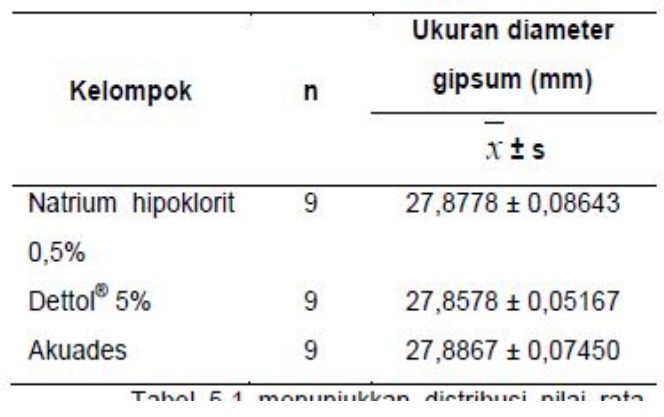

Tabel 5.1 menunjukkan distribusi nilai rata-rata diameter model gipsum berdasarkan jenis larutan penyemprotan. Hasil penelitian menunjukkan bahwa diameter terbesar model gipsum terjadi pada kelompok cetakan alginat yang disemprot dengan akuades, sedangkan diameter terkecil model gipsum terjadi pada kelompok cetakan alginat yang disemprot dengan Dettol® 5\%. Ukuran awal pada master cast yaitu $27,91 \mathrm{~mm}$. Hasil pengukuran rerata perubahan dimensi cetakan alginat setelah diberi perlakuan dapat dilihat pada tabel 5.2. 
Tabel 5.2 Hasil Perubahan Dimensi Setelah Penyemprotan

\begin{tabular}{lcccc}
\hline & \multicolumn{4}{c}{ Ukuran diameter gipsum (mm) } \\
& & \multicolumn{3}{c}{$\bar{x} \pm \mathbf{s}$} \\
\cline { 3 - 5 } Kelompok & N & $\begin{array}{c}\text { Master } \\
\text { Cast }\end{array}$ & $\begin{array}{c}\text { Sesudah } \\
\text { penyempr }\end{array}$ & Perubahan \\
otan \\
\end{tabular}

Tabel 5.2 menunjukkan hasil perubahan dimensi setelah penyemprotan pada masing- masing kelompok percobaan. Hasil penelitian menunjukkan bahwa perubahan dimensi terbesar terjadi pada kelompok cetakan alginat yang disemprot dengan Dettol® 5\%, sedangkan perubahan dimensi terkecil terjadi pada kelompok cetakan alginat yang disemprot dengan akuades.

Tabel 5.3 Hasil Uji Kruskal-Wallis Perbedaan Ukuran Dimensi Antara Kelompok Perlakuan

menunjukkan tidak terdapat perbedaan yang signifikan nilai pengukuran dimensi sesudah penyemprotan dengan natrium hipoklorit $0,5 \%$, Dettol ${ }^{\circledR} 5 \%$, dan akuades.

Tabel 5.4 Persentase Perubahan Dimensi

\begin{tabular}{cccc}
\hline Kelompok & $\mathbf{N}$ & $\begin{array}{r}\text { Perubahan } \\
\text { dimensi }\end{array}$ & $\begin{array}{c}\text { \% Perubahan } \\
\text { dimensi }\end{array}$ \\
\hline $\begin{array}{cccc}\text { Natrium } \\
\text { hipoklorit }\end{array}$ & 9 & $\begin{array}{l}-0,0322 \pm \\
0,08643\end{array}$ & 0,115 \\
$0,5 \%$ & & & \\
Dettol $^{\odot} 5 \%$ & 9 & $-0,0522 \pm$ & 0,187 \\
& & 0,05167 & \\
Akuades & 9 & $-0,0233$ \\
& & $\pm 0,07450$ & 0,083 \\
\hline
\end{tabular}

\section{PEMBAHASAN}

Rerata model gipsum menunjukkan nilai yang lebih kecil dibanding master cast. Hal ini disebabkan oleh proses imbibisi atau penyerapan cairan yang menyebabkan alginat mengembang dan menghasilkan dimensi model gips yang lebih kecil dibanding master cast. ${ }^{31} \mathrm{Hal}$ ini sesuai dengan penelitian yang dilakukan oleh Novitasari dkk (2013) yang mengatakan bahwa penyemprotan alginat dengan infusa daun sirih $25 \%$ menyebabkan ukuran model gipsum lebih kecil dibandingkan dengan master cast. $^{12}$ Perubahan dimensi yang terjadi disebabkan struktur alginat yang berbentuk serat dengan air yang mengisi ruangan kapiler tersebut. ${ }^{4}$ Perubahan dimensi yang terjadi pada penyemprotan dengan larutan natrium hipoklorit $0,5 \%$ terjadi karena adanya kandungan oksigen dalam larutan tersebut. Natrium hipoklorit merupakan senyawa yang terdiri dari oksigen. Oksigen merupakan oksidator yang kuat, sehingga terjadinya oksidasi dapat menyebabkan terjadinya fluktuasi tekanan pada larutan. Apabila natrium hipoklorit berkontak 
dengan bahan cetak alginat, maka tekanan dari larutan akan mendesak bahan cetak yang bisa menyebabkan hasil cetakan alginat lebih mudah mengalami imbibisi sehingga terjadinya perubahan dimensi. ${ }^{32}$ Perubahan dimensi yang terjadi pada penyemprotan dengan larutan Dettol® 0,5\% terjadi karena adanya kandungan fenol dalam larutan tersebut. Kandungan fenol bila berkontak dengan bahan cetak alginat akan terjadi reaksi esterifikasi, yaitu reaksi pembentukan ester dengan berikatan dengan sebuah asam karboksilat yang terkandung dalam struktur kimia alginat. Adanya kandungan $\mathrm{H} 2 \mathrm{O}$ pada hasil reaksi esterifikasi tersebut serta sifat alginat yang mudah mengalami imbibisi dapat mengakibatkan perubahan dimensi yang lebih besar dibandingkan dengan kelompok kontrol. ${ }^{32,33,34}$

Muzaffar dkk (2011) mengatakan cetakan alginat yang berkontak dengan larutan desinfektan menyebabkan terjadinya perubahan dimensi karena adanya penyerapan larutan desinfektan oleh alginat menyebabkan terjadinya ekspansi bahan cetak, dimana bahan cetak alginat mengandung ion-ion seperti $\mathrm{Na}$, SO42-, dan PO43- sebagai potensial osmotik.35 Saito dkk (1998) juga mengatakan bahwa tekanan osmotik antara gel alginat dan larutan desinfektan menyebabkan alginat mengalami ekspansi atau pengembangan. ${ }^{4,36}$
Berdasarkan penelitian yang telah dilakukan, hasil uji Kruskal- Wallis menunjukkan bahwa perbedaan ukuran dimensi pada kelompok cetakan alginat yang disemprot dengan larutan natrium hipoklorit 0,5\%, Dettol® 5\%, dan akuades tidak signifikan. Hal ini terjadi karena cairan yang diabsorbi lebih sedikit serta waktu penyemprotan yang relatif tidak terlalu lama sehingga tidak menyebabkan perubahan dimensi yang terlalu besar. Hal ini sesuai dengan penelitian Parimata dkk (2014) yang mengatakan bahwa tidak terdapat perbedaan yang bermakna pada cetakan alginat yang dilakukan penyemprotan dengan infusa daun sirih merah $50 \%$ dan natrium hipoklorit $0,5 \%$ yang disimpan dalam waktu 10 menit. $^{4}$

Cetakan alginat yang disemprot mengalami perubahan dimensi yang lebih kecil karena cairan yang diabsorbsi oleh bahan cetak alginat lebih sedikit. Pada teknik ini terjadi keseimbangan antara proses imbibisi dan sineresis. Imbibisi terjadi pada saat larutan desinfektan disemprotkan pada cetakan alginat, sedangkan sineresis terjadi setelah dilakukan penyemprotan, yaitu ketika cetakan alginat dibiarkan dalam kantung plastik, sehingga proses masuk dan keluarnya partikel air ke dalam alginat terjadi secara seimbang. ${ }^{1}$

Berdasarkan standar ADA no 18, bahan cetak alginat tidak boleh mengalami 
perubahan lebih dari $0,5 \%$ dari ukuran master cast, karena perubahan yang terjadi akan mempengaruhi keberhasilan tahap pekerjaan selanjutnya, seperti pembuatan gigi tiruan penuh dan gigi tiruan sebagian. $^{17,37}$

Pada tabel 5.4 menunjukkan bahwa penyemprotan cetakan alginat dengan larutan natrium hipoklorit 0,5\%, Dettol ${ }^{\circledR}$ 5\% dan akuades menyebabkan perubahan dimensi berkisar $0,083 \%$ - 0,187\%, dimana persentase perubahan dimensi ini masih dalam batas standar yang telah ditetapkan oleh ADA. Oleh karena stabilitas dimensi cetakan alginat setelah penyemprotan dengan larutan natrium hipoklorit 0,5\%, Dettol® 5\% dan akuades yang dimasukkan ke dalam kantung plastik selama 10 menit memenuhi standar menurut ADA, maka cetakan alginat setelah dilakukan desinfeksi dapat dilanjutkan untuk proses pengecoran model gigi tiruan dan model studi.

\section{KESIMPULAN}

Dari hasil penelitian yang telah dilakukan maka dapat disimpulkan bahwa:

1. Terdapat perubahan dimensi pada cetakan alginat yang disemprot dengan larutan natrium hipoklorit.

2. Terdapat perubahan dimensi pada cetakan alginat yang diseprot dengan larutan Dettol® $5 \%$.
3. Tidak terdapat perbedaan stabilitas dimensi yang signifikan antara cetakan alginat yang disemprot dengan larutan natrium hipoklorit $0,5 \%$ dan Dettol® $5 \%$.

\section{KEPUSTAKAAN}

1. Sari DF, Parnaadji RR, Sumono A. Pengaruh Teknik Desinfeksi dengan Berbagai Macam Larutan Desinfektan pada Hasil Cetakan Alginat Terhadap Stabilitas Dimensi. J Pustaka Kesehatan. 2013; 1(1): 29-34.

2. Febriani M. Pengaruh Penambahan Pati Ubi Kayu Pada Bahan Cetak Alginat Terhadap Stabilitas Dimensi. IDJ. 2012; 1(1): 1-5.

3. Anusavice KJ. Philip's Science of Dental Materials.11th ed. St.Louis. Elsevier. 2003; 206-253.

4. Parimata VN, Rachmadi P, Arya IW. Stabilitas Dimensi Hasil Cetakan Alginat Setelah Dilakukan Penyemprotan Infusa Daun Sirih Merah (Piper crocatum Ruiz \& Pav) $50 \%$ Sebagai Desinfektan. Dentino (Jur Ked Gigi). 2014; 2(1): 74-78.

5. Santoso EDL, Widodo TT, Baehaqi M. Pengaruh Lama Perendaman Cetakan Alginat Dalam Larutan Glutaraldehid 2\% 
Terhadap Stabilitas Dimensi.

Odonto Dental Journal. 2014; 1(2): 35-39.

6. Kakatkar VR. Complete Denture Impression Techniques Practiced by Private Dental Practitioners: A survey. J Indian Prosthodont Soc. 2013; 13(3): 233-235.

7. Rad FH, Ghaffari T, Safavi SH. In Vitro Evaluation of Dimensional Stability of Alginate Impressions after Disinfection by Spray and Immersion Methods. J Dent Res Dent Clin Prospect. 2010; 4(4): 130-135.

8. Dulaimi SF, Al-Wahab ZN. The Effect of Desinfectants On The Surface Quality of Irreversible Hydrocolloid Impression Material and Gypsum Cast. Iraqi National $\mathbf{J}$ Nursing Specialities. 2012; 25(1): 95-100.

9. Sukhija U, Rathee M, Kukreja N, Khindria S, Singh V, Palaskar J. Efficacy of Various Disinfectant on Dental Impression Materials. IJDS. 2009; 9(1): 1-9.

10. Khalid M, Shah SN, Chughai A. Comparison of Mean Dimensional Measurement of Alginate Impression Using Sodium Hypochlorite Versus Glutaraldehyde and Benzalkonium
Chloride for Desinfection. JKCD. 2015; 5(2): 43-48.

11. Badrian H, Ghasemi E, Khalighinejad.XThe Effect of Three Different Disinfection Materials on Alginate Impression by Spray Method. ISRN Dentistry. $2015 ; 1-5$.

12. Novitasari RDA, Meizarini A, Soekartono RH. Teknik Desinfeksi Cetakan Alginat Dengan Infusa Daun Sirih $25 \%$ Terhadap Perubahan Dimensi. Material Dental Journal. 2013; 4(1): 33-38.

13. Qamruddin I, Siddiqui AZ, Butt S. Disinfection of Dental Impressions: A Survey of Private Practices and Dental Universities in Karachi, Pakistan. JPDA. 2011; 20(1): 1922.

14. Savitri AI, Djulaeha E, Subianto A. Efektivitas Penyemprotan Ekstrak Daun Sirsak (Annona muricata L) Sebagai Desinfektan Koloni Mikroorganisme Pada Cetakan Alginat. J Pros. 2013; 4(2): 1-6.

15. Bustos R, Herrera R, Gonzalez U. Martinez A. Effect of Immersion Desinfection With $0,5 \%$

1. Sodium Hypochlorite ang $2 \%$ Glutaraldehyde on Alginate and Silicone: Microbiology and SEM 
Study. Int J. Odonstomat. 2010; 4(2): 169- 177.

16. Ongo TA, Rachmadi P, Arya IW. Stabilitas Dimensi Hasil Cetakan Bahan Cetak Elastomer Setelah Disemprot Menggunakan Sodium Hipoklorit. Dentino (Jur Ked Gigi). 2014; 2(1): 83-88.

17. Hasanah NY, Arya IW, Rachmadi IP. Efek Penyemprotan Desinfektan Larutan Daun Sirih 80\% Terhadap Stabilitas Dimensi Cetakan Alginat. Dentino (Jur Ked Gigi). 2014;. 2(1): 65-69.

18. Council on Dental Materials, Instruments, and Equipment. Infection Control Recommendations for The Dental Office and The Dental Laboratory. ADA Council on Scientific Affairs and ADA Council on Dental Practice. J Am Dent Assoc. 1988; 116: $241-248$

19. Khaledi AAR. Mahdavi F, Heidary H. Dimensional Stability of ColorChanging Irreversible Hydrocolloids After Desinfection. J Dent Biomater. 2015; 2(1): 2932.

20. Joana CS, Margarida TA, Andrea S, Tania P, Benedita SM, Mario V. The Effect of Water and Sodium Hypochlorite Disinfection on
Alginate Impressions. Dent Cir Maxilofac. 2013; 54:8-12.

21. Dorner AR, Silva JMFD, Uemura ES, Borges AL, Fernandes Junior VB, Yamamoto EC. Effect of Disinfection of Irreversible Hydrocolloid Impressio Materials With 1\% Sodium Hypochlorite on Surface Roughness and Dimensional Accuracy of Dental Stone Casts. Eur J G Dent.2014; 113-119.

22. Badrian H, Davoudi A, Molazem M. The Effect of Spraying Different Disinfectants on Condensational Silicone Impressions; An In Vitro Study. J Indian Prosthodontic Soc. 2015; 263-267.

23. Radcliffe CE, Potouridou L, Qureshi R, Habahbeh N, Qualtrough A, Worthington $\mathrm{H}$, Ducker DB. Antimicrobial Activity of Varying Concentrations of Sodium Hypochlorite on The Endodontic Microorganisms Actinomyces israeli, A. Naeslundii, Candida albicans and Enterococcus faecalis. Int Endod J.2004; 438-446.

24. Ghahramanloo A, Sadeghian A, Sohrabi K. A Microbiologic Investigation Following the 
Disinfection of Irreversible

Hydrocolloid Material Using the Spray Method. CDA J.2009; 37(7): 471-477.

25. Gopal L, Palwankar P, Verma A, Chadha VS, Dhalia N. Dettol- A Rare Allergen. Dental Lamina- J Dent Sci. 2015; 3(1). 40-41.

26. Saha AK, Haque MF, Karmaker S, Mohanta MK. Antibacterial Effect of Some Antiseptics and Desinfectants. J. Life Earth Sci. 2009; 3: 19-21.

27. Mahmood EL, Doughari JH. Effect of Dettol on Viability of Some Microorganisms Associated With Nosocomial Infections. Afr J Biotechno. 2008; 7(10): 15541562 .

28. Jouda MM, Dardona Z, Albayoumi M. The Antibacterial Effect of Some Household Detergents Againts Staphylococcus Aureus. Int J Curr Microbiol App Sci. 2016; 5(2): 459- 463.

29. Ramadhani. Pengaruh Perendaman Cetakan Alginat Dalam Larutan Desinfektan Sodium Hipoklorit dan Dettol 5\% Terhadap Perubahan Dimensi. Skripsi. Aceh: Universitas Unsyiah Kuala. 2016.
30. Brown TL, Lemay HE, Bursten BE, Murphy CJ, Woodward MP. Chemistry The Central Science Twelve Edition. Prentice Hall USA. 2012; 142-143.

31. Imbery TA, Nehring J, Janus C, Moon PC. Accuracy and Dimensional Stability of ExtendedPour and Conventional Alginate Impression Materials. J Am Dent Assoc. 2010; 141:32-39.

32. Zeni MA, Kristiana D, Fatmawati DWA. Pengaruh Rebusan Daun Salam (Eugenia polyantha Wight) $100 \%$ dan Sodium Hipoklorit $(\mathrm{NaOCl}) \quad 1 \%$ terhadap Stabilitas Dimensi Hasil Cetakan Hidrokoloid Ireversibel. E-J Pustaka Kesehatan. 2015; 3(3): 555-559.

33. Husain A. Medicinal Chemistry, Chemotherapy: Antiseptic and Desinfectant. Fac Farmacy Jamia Hamdard New Delhi. 2008; 1-8.

34. Mila AZ, Kristiana D, Fatmawati DWA. Pengaruh Rebusan Daun Salam (Eugenia polyantha Wight) 100\% dan Sodium Hipoklorit $(\mathrm{NaOCl})$ 1\% sebagai Desinfektan Terhadap

2. Stabilitas Dimensi Hasil Cetakan Alginat. JKG Unej. 2014; 12-15. 
35. Muzaffar D, Ahsan SH, Afaq A. Dimensional Change in Alginate Impression During Immersion in A Disinfectant Solution. J Pak Med Assoc. 2011; 61(8): 756- 759.

36. Saito S, Ichimaru T, Araki Y. Factor Affecting Dimensional Instability of Alginate Impression During Immersion in the Fixing and Disinfectant Solutions. J Dent

Material. 1998; 4: 294-300.

37. Sudjarwo I, Saleh NN. Pengaruh Perendaman Cetakan Alginat Dalam Larutan Desinfektan Sodium Hipoklorit dan Perasan Aloe Vera Terhadap Stabilitas Dimensional. J Ilmiah. 2015; 2-3. 